See discussions, stats, and author profiles for this publication at: https://www.researchgate.net/publication/322499803

The Effect of Compensation, Organizational Culture and Islamic Work Ethic Towards the Job Satisfaction and the Impact on the Permanent Lecturers

Article in International Business Management · October 2017

DOI: $10.3923 / \mathrm{ibm} .2017 .53 .60$

4 authors, including:

Some of the authors of this publication are also working on these related projects:

Human Resources Management View project 
International Business Management 11 (1): 53-60, 2017

ISSN: $1993-5250$

(C) Medwell Journals, 2017

\title{
The Effect of Compensation, Organizational Culture and Islamic Work Ethic Towards the Job Satisfaction and the Impact on the Permanent Lecturers
}

\author{
${ }^{1}$ Jufrizen, ${ }^{2}$ Prihatin Lumbanraja, ${ }^{2}$ Sitti Raha Agoes Salim and ${ }^{3}$ Parapat Gultom \\ ${ }^{1}$ School of Economic and Business, University of Sumatera Utara, Medan, Indoenesia \\ ${ }^{2}$ Faculty of Economics and Business, ${ }^{3}$ Faculty of Mathematics and Natural Sciences, \\ University of Sumatera Utara, Medan, Indonesia
}

\begin{abstract}
This study examines the effect of compensation, organizational culture and Islamic work ethic directly towards the job satisfaction and performance of the lecturers and the effect of compensation, organizational culture and Islamic work ethic towards the performance of lecturers through job satisfaction. This study was conducted at the Private Islamic University in Indonesia. The population of the study is 295 lecturers. The data were analyzed using The Structural Equation Modeling with LISREL 8.80 applications. The results showed that compensation, organizational culture and Islamic work ethic have a positive and significant effect on job satisfaction. Job satisfaction has a positive effect on the performance. Compensation, organizational culture and Islamic work ethic have a positive effect on the performance of lecturers significantly. Compensation and organizational culture have a significant effect on the performance through job satisfaction while Islamic work ethic does not significantly influence the performance of lecturers through job satisfaction.
\end{abstract}

Key words: Compensation, organizational culture, Islamic work ethic, job satisfaction, lecturers, performances

\section{INTRODUCTION}

The problem of quality of university graduates should not be separated from the role of lecturers who have a strategic role in making the high-quality graduates as they directly hold a very important role in the teaching and learning processes at the college in which they daily try with all their strength to transfer their knowledge to the students. According to Suparno, lecturer is one of the human resources who have an important role in the educational process. Until now, the attention to the performance of the lecturers has been given in many ways including training, comparative study, workshops, etc. There are also some opportunities provided to improve the education to the higher level either independently or through a scholarship from the government. The results have been perceived through the improving quality of education or through the achievements shown by the college students both during the education and after entering the workforce.

The field fact proves that the performance of lecturers is the primary in improving the intelligence of the nation's life which has not shown the optimal performance yet. It can be seen from the observation and interviews that there are still many lecturers who do not make the Lecture
Unit Satuan Acara Perkuliahan (SAP) and Basic Teaching Outline Garis Besar Pokok Pengajaran (GBPP), the lecturers who come to the classroom and go home out of the schedule who do not return the homeworks or assignments to the student who late-submit the results of the tests who tend to use the same study methods for all subjects who do not use the teaching aids who dominate the learning processes who are less innovative and rarely providing exercises to the students as the implementation of the taught theories or principles in the classroom into practices exercises and who make ultimately unsatisfactory results on students' learning processes. These conditions are consistent with the results of research conducted by Wiyono (2009) which concludes that the performance of lecturers is still low, proved by the careless teaching given by the lecturers, the seldom library visit to improve their knowledge, the few studies and scientific papers produced.

Maharsi states that ten variables of lecturers' teaching performance include the discipline in teaching attendance, punctuality in starting and ending the lecture, behavior attitude in the lecture, intonation and volume in the lecture, role in encouraging the learning motivation of students to get some achievements, to be systematic in explaining the courses, mastery of the courses material,

Corresponding Author: Jufrizen, University of Muhammadiyah Sumatera Utara (UMSU) Jl Kapt Mukhtar Basri No.3, 20238 Medan, Indonesia 
the suitability to the syllabus, actuality relevance application of the course, familiarity and friendliness during the lecture.

The performance of the lecturers is influenced by job satisfaction. This is in accordance with the opinion of Reyes and Shin (1998) which state that the job satisfaction of the lecturers is a major determinant of the commitment of the lecturers and is associated with their retention. Whiteford identifies several indicators of lecturers' satisfaction with their research and sense of accomplishment that includes positive relationships with their colleagues, satisfactory working conditions and the prestige and dignity associated with teaching ( $\mathrm{Na}$ et al., 2011). The results of research by Ghazi et al. (2010) showed that the lecturers will be satisfied with the variety of work, creativity, moral values, compensation, job, teamwork, responsibility, ability ulization, authority, activity, social status, job security, achievement and student interaction. Further research by Ali (2005) found that all independent factors such as promotions, supervisor behavior, work environment, compensation and conflict are the significant predictors of job satisfaction.

In some private universities in Medan, it is found that the level of job satisfaction of the lecturers is still low. It is thought to be caused by inadequate compensation, lack of working facilities, the less-conducive organizational culture and not good career system. The compensation system for lecturers who apply in some private universities in Medan is still adhered to the conventional system which refers to the compensation system for the Civil Servants (PNS) that the indicator is the time of devotion and working class. The compensation received is only in the form of fixed salary (still equivalent to the salary of civil servants in 2003) in accordance with a predetermined credits (SKS) of 12 credits and if there is an excess on credits, it will be paid for teaching fees adapted to the applicable functional position.

The performance and job satisfaction of the lecturers are of course influenced by the complex factors, not only from the compensation, but also by the vision, mission and value systems and beliefs in the environment in which the lecturers work, as reflected in the culture of the organization, especially in the Private University (PTS). In general, the organizational culture is invented or created by the founder or the leader of the top management or the pioneer who founded the organization. The philosophy or strategy established by the founder and then becomes the instructions and guidelines for their subordinates in carrying out their duties. The Universities which concern to the organizational culture will be able to improve the performance of the employees (Syed et al., 2012).
There is a need of a good work ethic in order to improve the performance and job satisfaction of the lecturers. Raharjo (2001) states that the work ethic is very dominant for the success of one's work maximally, in terms of the consciousness or cultural values embraced by human are very decisive. So in the economic development, the work ethic is affecting and decisive to human behavior. The work ethic is the most studied subject, since Max Weber introduced the Protestant work ethic, which is associated with productivity and economic development of the countries in Europe based on the Protestant religion (Ali, 2005). Max Weber states that the Protestant community has a special work ethic that is different from non-Protestant communities (Judge and Bono, 2001), called as Protestant work ethic (Protestant Work Ethic, PWE). Ali (2005) states that several studies on the effect of work ethic on productivity and performance by using the PWE instrument is a fundamental bias, because the culture and value systems prevailing in Arab society (Islam) is different from European and American societies. According to Ali (2005) one of the pillars of Protestant Work Ethic is the relationship between the work ethic and the individual. The results of research by Lubis showed that the lecturers who are increasingly understanding the norms or rules applied both in the ethic code and the dimensions of accountability, justice and truth in the work ethic of Islam which is based on sharia law will actually perform their duties and functions as the lecturers.

\section{MATERIALS AND METHODS}

Type of research: It is an explanation study or a kind of explanation of the knowledge resulted from a study. The scope of explanation is divided into causality and non-causality comparative study (Fiofori, 2007). The method used in this study is survey.

Population and sample: The population of the study is all of the lecturers of Private Universities in Medan Indonesia which are owned by Islamic Foundation (Organization). There are 295 permanent lecturers who have functional positions as Instructor (Asisten Ahli), Assistant Professor (Lektor) and Associate Professor (Lektor Kepala) which have some following characteristics: work period for more than 1 year, have a domicile in Medan and implement the Three Pillars of University. The sampling technique used in this study was conducted by saturated sampling that is a sampling technique if all of the population members are used as the sample. 
Metode analisis: The data were analyzed using The Structural Equation Modeling (SEM) from a package of statistical software LISREL 8.80 in hypothesis model and review.

\section{RESULTS AND DISSCUSION}

The results of estimation of all causal relationships of the study can be seen on the following output of LISREL 8.80: conceptual frame work shown in Fig. 1.

\section{Hypothesis testing}

The hypothesis testing of direct effects: The results of direct effects testing are as follows: according to the Table 1 above in which consists of the conclusions of the results of study model hypothesis, it can be concluded in some following ways as follows.

The effect of compensation towards the job satisfaction: The hypothesis states that compensation has a positive and significant effect on job satisfaction of the lecturers. Based on the results of data processing of the structural model, the output obtained a t-value of 5.25. The results of the t-value showed by the hypothesis is $>1.96$, it can be concluded that the compensation has a positive and significant effect on job satisfaction. Thus, the hypothesis is acceptable and it can be concluded that the higher the compensation received by the permanent Lecturers of Private Islamic University in Medan, the better the job satisfaction.
The results are suited to the opinion from Lockyer cited by Irianto which states, "The system of compensation is an internal part in industrial relations and affects the effectiveness of the relationship between organizations and employees". In the results of Annual Job Satisfaction Survey on the corporate staffs in the United States with regard to the compensation problem nearly to year of 2000 showed that the highest level of employee dissatisfaction revolves around salaries, bonuses and the relationships between the payment and work of the employees.

Steers finds one of the ways to increase employee satisfaction by providing a satisfactory compensation. According to Maslow with the theory of Hierarchy Need says that a person's behavior in a particular moment is determined by the strongest needs so that the employee is working to fulfill those needs. The results of this study is in line with the results of study by Miller about the effect of compensation to the job satisfaction conducted in one of the universities in the United States, concluded that the "top most factors in producing job satisfaction include financial resources, faculty workload and technology impact “. Likewise, a study by Noe (2008) states that the compensation system has a significant positive effect towards job satisfaction lecturers, either partially or simultaneously. Chaudhry et al. (2011) states that salary satisfaction is positively related to job satisfaction. The salary satisfaction is proved to be a facilitator that is designed to increase the level of employees satisfaction. Furthermore, a study by
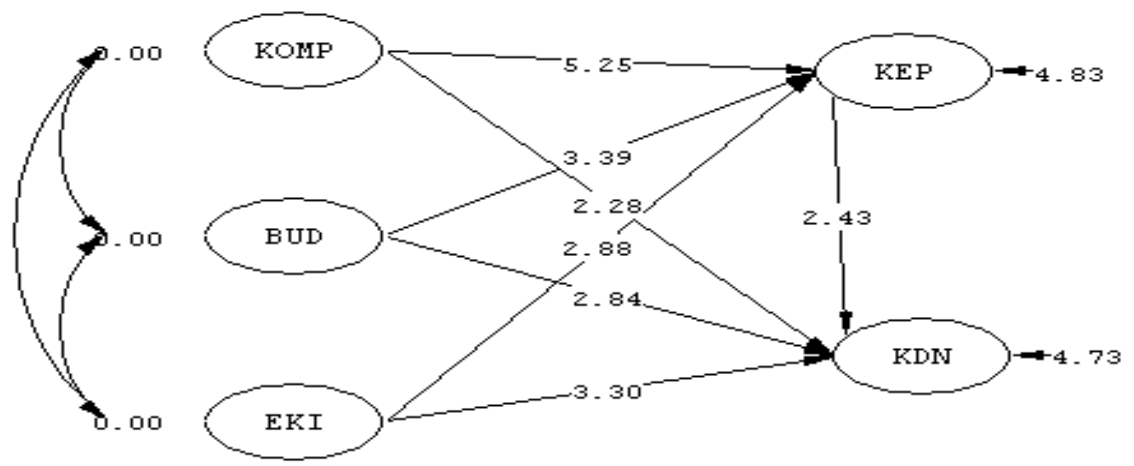

Fig. 1 : Conceptual framework

\begin{tabular}{|c|c|c|c|}
\hline Hypothesis & Statement & t-values & Information \\
\hline 1a & Compensation towards job satisfaction & 5.25 & Acceptable \\
\hline $1 b$ & Organizational culture towards job satisfaction & 3.39 & Acceptable \\
\hline $1 \mathrm{c}$ & Islamic work ethic & 2.88 & Acceptable \\
\hline $2 a$ & Compensation towards lecturers' performances & 2.28 & Acceptable \\
\hline $2 b$ & Organizational culture towards lecturers' performances & 2.84 & Acceptable \\
\hline $2 c$ & Islamic work ethic towards lecturers' performances & 3.30 & Acceptable \\
\hline 3 & Job satisfaction towards lecturers' performances & 2.43 & Acceptable \\
\hline
\end{tabular}

Output of LISREL 8.80 (2015) 
Lai (2011) concluded that there is a positive correlation between employees satisfaction and work-based salry, skill-based salary and performance-based salary. These results are consistent with the results of the studies by Sopiah (2013), Choudhury and Mishra (2010) and Nawab and Bhatti (2011).

The effect of organizational culture towards job satisfaction: The hypothesis states that the organizational culture has a positive and significant effect towards job satisfaction. Based on the results of data processing of structural model, the output obtained a t-value of 3.39 . The t-value showed by hypothesis is $<1.96$, so that it can be concluded that organizational culture has a positive and significant effect towards job satisfaction. Thus, the hypothesis can be accepted and concluded that the better the Organizational Culture of Private Islamic University in Meddan does not affect the job satisfaction.

The results of this study also support the theory of Robbins $(1996,1989)$ states that the employees create an entire subjective perception about organization. This study is in line with the results of studies by Rogga (2001), Lund (2003), Sangadji (2013) and Sopiah (2013).

The effect of Islam ic work ethic towards job satisfaction: The hypothesis states that the Islamic work ethic has a positive and significant effect towards lecturers job satisfaction. Based on the results of data processing of structural model, the output obtained a t-value of 2.88 . The t-value showed by hypothesis is $>1.96$, so that it can be concluded that Islamic work ethic has a positive and significant effect towards job satisfaction.

This study is in line with the studies conducted by Yousef $(2001,2000)$ Koh and Boo (2001), Tampubolon (2007) and Elkins (2007) which found that there is a weak correlation between work ethic and job satisfaction in Japanese manufacturing companies. However, Lambert and Hogan (2009) found that work ethic has the biggest impact on job satisfaction. The Islamic work ethic sees that a job as an important meaning for someone's future economically, socially and psychologically to give some pride, to increase the social welfare and to strengthen the faith (Ali, 2005). Working is the source of richness and welfare (Akbarnejad and Chanzanagh, 2012), it is in line with the principle of work as the source of ownership.

The effect of compensation towards the lecturers' performances: The results showed that the higher the compensation received by the Permanent Lecturers of Private Islamic University in Medan, the higher the performance of the lecturers. It is in line with the results of studies by Paik et al. (2007), Sopiah (2013) which showed that the compensation of the employees has a significantly positive effect towards the performance of the employees. One of the management ways to improve the performance of the employees is through the compensation (Mathis and Jackson, 2002). Simamora states that financial compensation is important for the employees because by the compensation they can fulfill they needs directly, especially for the physiological needs.

The effect of organizational culture towards the lecturers' performances : The hypothesis states that the organizational culture has a positive and significant effect towards the lecturers' performances. Based on the results of data processing of structural model, the output obtained a t-value of 2.84. The t-value showed by hypothesis is more than 1.96 , so that it can be concluded that organizational culture has a positive and significant effect towards lecturers' performances.

The results of this study support the theory proposed by Robbins (1996) which states that the employees create an entire subjective perception about the organization based on he factors such as tolerance to the risk, emphasize to the team and other workers supports. The supporting or not perceptions then affect the performance and job satisfaction of the employees, with the bigger impact on the stronger culture. The more the members accept those values, the stronger the organizational culture. A strong organizational culture will result in a high job satisfaction and performance, otherwise, a weak organizational culture will result in a low job satisfaction and performance.

Kotter (2012) state that a strong culture is often said to help the performance because it creates a tremendous level of motivation to the employees. Gordon states that the success of a company depends on its success in creating a distinctive organizational culture as part of a strategic plan. Furthermore, he states that the suitability between the employees' attitude and behavior with the organizational culture have an effect on their performance.

A study conducted by Sheridan (1992) showed that organizational culture is significantly positively related to the employee performances, voluntary turnover and organizational commitment. It is said that variations in cultural values have an effect on the level of turnover and employee performances. A study by Chen (2004) showed that organizational culture and leadership style have a significant positive effect on organizational commitment, job satisfaction and employee performance. Studies by Sangadji (2013, 2009) and Mulyono and Nasir (2012) concluded that organizational culture has a positive effect 
on the performance of lecturers. Rashid in Sopiah (2013) shows that organizational culture is closely related to the employee commitment and has a significant effect on the performance. Ogbor argues that organizational culture which gives a sense of comfort in working and high confidence will increase in work behavior.

The effect of islamic work ethic towards the lecturers' performance: The hypothesis states that the Islamic work ethic has a positive and significant effect towards the lecturers' performance. The t-value showed by hypothesis is $<1.96$, so that it can be concluded that Islamic Work Ethic has a positive and significant effect towards the lecturers' performance. This study is in line with the studies conducted by Yousef (2001) and Koh and Boo (2001).

Islamic work ethic gives some reasons for the lecturers to adjust the values of their lives with the values of the organization. If there is a harmony between personal ethics and the organization's ethics, the lecturers' performance will increase. Islam work ethic emphasizes cooperation, integrity and social responsibility. Islam teaches that people should help each other in goodness. In Islamic work ethic, no matter how small the business, is very appreciated. Cooperation is one of the results of togetherness. Mondy (2008) in Ridwan (2013) explains that the main orientation of Islamic work ethic is working. Islamic work ethic regards the individuals who are working hard to find favor, fortune in the contentment of the Almighty is the nature and believed to achieve success in life, while those who do not work hard will find the failure in life. Anyone who works hard will get a reward. This principle applies to every individual and to all people "But Allah will not change the fate of a nation, until they change what is in themselves" (Q.S. Al-Anfal: 53).

The effect of job satisfaction towards the lecturers' performance: The $t$-value showed by hypothesis is $>1.96$, so that it can be concluded that job satisfaction has a positive and significant effect towards the lecturers' performance. Thus, the hypothesis is acceptable and can be concluded that the higher the job satisfaction perceived by the permanent lecturers of Private Islamic University in Medan, the better the performance of the lecturers.

Job satisfaction has been extensively studied over the last four decaded in the studies on organization (Currivan, 1999), in Daulatram. A number of studies have examined the relationship between job satisfaction and various organizational variables, including the relationship between job satisfaction and performance
Table 2: Hypothesis testing of indirect effects

\begin{tabular}{lc}
\hline Hypothesis & $\begin{array}{c}\text { Through } \\
--------\end{array}$ \\
\hline $\begin{array}{l}\text { Indirect effect (thitung } \\
\text { The effect of compensation towards the } \\
\text { performance of the lecturers }\end{array}$ & 2.30 \\
$\begin{array}{l}\text { The effect of organizational culture } \\
\text { towards the performance of the lecturers }\end{array}$ & 2.05 \\
$\begin{array}{l}\text { The effect of Islamic work ethic towards } \\
\text { the performance of the lecturers } \\
\text { The effect job satisfaction towards the } \\
\text { performance of the lecturers }\end{array}$ & 1.91 \\
\hline
\end{tabular}

Output of LISREL 8.80, processed by the researcher (2015)

(Lawler III and Porter, 1967; Locke, 1970; McGivern and Tvorik, 1997). The statement that job satisfaction and work attitudes related to employee performance has been showed by Iaffaldano and Muchinsky that there is a weak positive correlation. While others are based on a meta-analysis of Petty et al. (1984) showed a strong positive relationship between job satisfaction and employee performance (Kim, 2002). Although, there is disagreement among the researchers on the relationship between job satisfaction and employee performance, those studies reveal that employees are who more satisfied have lower absenteeism and turnover (Tett and Meyer, 1993)

The results of study conducted Ostroff (1992) show a positive relationship between job satisfaction and employee performance. Further disclosed more specifically, an organization with employees who are more satisfied, committed, appropriate and do not have a high stress will have a higher performance level than those who are less satisfied, less committed, less capable to adjust and have more stress.

Hypothesis testing of indirect effects: The results of indirect effects testing are as follows: shown in Table 2 Based on the testing of intervening variables, it is proved that job satisfaction is the intervening variable for compensation and organizational culture effects towards the performance of lecturers through job satisfaction. It means that the better the compensation given, the stronger the organizational culture, the more satisfied the lecturers in working, thus it has an effect on the bettter performance of lecturers. Meanwhile, the Islamic work ethic does not significantly affect the performance of lecturers through their job satisfaction. The results of the test show that in order to improve the performance of the permanent lecturers in Private Islamic University in Medan, the determinant factor is the Islamic work ethic without going through job satisfaction. Islamic work ethic plays a key role towards improving the performance of permanent lecturers of Private Islamic University in Medan. 


\section{CONCLUSION}

- Compensation, organizational culture and Islamic work ethic have a positive effect on job satisfaction significantly

- Compensation, organizational culture and Islamic work ethics have a positive and significant effect on the performance of lecturers

- Job satisfaction has a positive effect on the performance of the lecturers significantly

- Compensation and organizational culture have a significant effect on the performance of lecturers through job satisfaction, while Islamic work ethic does not significantly affect the performance of lecturers through job satisfaction

\section{IMPLICATIONS}

- Theoretically, the results of this study have som implications for the importance of the wider development of the theories about Islamic work ethic. The work ethic. The work ethic is not always seen from the aspect of religious belief, the values of work ethic can be seen from the various dimensions of personal behavior and culture

- Practically, the results of this study provide an overview to the managers of Private Islamic University in Medan on the importance of compensation, organizational culture, Islamic work ethic, job satisfaction, organizational commitment and performance of permanent lecturers for the sake of the progress of its education progress and the quality of the graduates

\section{LIMITATIONS}

- Islamic work ethic is served as the independent variable (exogenous). Some studies concluded that Islamic work ethic is a moderating variable

- Not all Islamic universities in Medan are served as the research object, only the private Islamic Universities which owned by the Islamic organizations become the object of study, so that the results can not be generalized to other Islamic Universities

\section{RECOMMENDATIONS}

After considering the conclusions, implications and limitations of the study, the followings are the recommendations which can be proposed, as follows:
- To use this study model as the basis for the development of future study model with some expectation that the development of future study model can create more complete models and incorporate new variables which are the causal factors of job satisfaction and performance of lecturers

- There is a need for further study on compensation, organizational culture and Islamic work ethics associated with various behavioral variables in addition to job satisfaction, organizational commitment and performance

- There is a need to improve the intensity of study on Islamic work ethic within the educational organizations institutions. This is important because the ethical issues are the fundamental problems in both individual, organizational and social life

\section{SUGGESTIONS}

- To the Management of University (College)

- The management of University (College) should try to prosper the lecturers either in the form of material financial such as wages, salaries, incentives and allowances, as well as non-material in the form of certainty and smoothness in career, a comfortable working atmosphere and togetherness that will be able to increase job satisfaction, organizational commitment and performance of lecturers

- In building the organizational culture, the Management of University (College) needs to pay attention to the values contained in the construct of organizational culture so that it can improve the coordination of work with the involvement of lecturers in the form of the lecturer team that will create a culture of cooperation among the lecturers.

- The management of University (College) needs to make various programs that are able to foster the mental and spiritual and also Islamic work ethic and moral of the lecturers so they can have a behavior that can increase job satisfaction, organizational commitment and their performance

- In creating lecturers' job satisfaction, the management of university (college) needs to give an opportunity to every lecturer to be a structural official with a fair and transparent system. The management needs to appreciate the lecturers' work to make them more appreciated

- In establishing the performance of lecturers, the management should encourage the creation of conducive condition to establish the educational and teaching, research and community service activities as well as the supporting activities 
- To other researcher

- It is suggested that the future research could add other variables, so it will obtain a more complete model of the factors that influence job satisfaction, organizational commitment and performance of lecturers

- The future research should enrich the indicators of variable of the lecturers' performance

\section{REFERENCES}

Akbarnejad, M. and H.E. Chanzanagh, 2012. Protestant work ethic, gender role attitudes, ethnicity and class: Case of Iran. Int. J. Soc. Sci. Humanity, 2: 270-270.

Ali, A., 2005. Islamic Perspectives on Management and Organization. Edward Elgar, Cheltenham, England, ISBN: 1-84376-766-X, Pages: 247.

Chaudhry, M.S., H.M. Sabir, N. Rafi and M.N. Kalyar, 2011. Exploring the relationship between salary satisfaction and job satisfaction: A comparison of public and private sector organizations. J. Commerce, 3: $1-14$.

Chen, L.Y., 2004. Examining the effect of organization culture and leadership behaviors on organizational commitment, job satisfaction and job performance at small and middle-sized firms of Taiwan. J. Am. Acad. Bus., 5: 432-438.

Choudhury, D. and S. Mishra, 2010. The compensation-satisfaction correlation at workplace: A study on BPOs at Orissa. Int. J. Bus. Manage. Tomorrow, 1: 1-15.

Currivan, D.B., 1999. The causal order of job satisfaction and organizational commitment in models of employee turnover. Human Resour. Manage. Rev., 9: 495-524.

Elkins, S.L., 2007. Job satisfaction and work ethic among workers in a Japanese manufacturing company located in the United States. Ph.D Thesis, The University of Tennessee, Knoxville, Tennessee.

Fiofori, F.O., 2007. Organizational cultures: Use nanotechnology communication format to achieve goals. J. Bus. Public Affairs, 1: 33-44.

Ghazi, S. R., R. Ali, G. Shahzada and M. Israr, 2010. University teachers job satisfaction in the North West fontier province of Pakistan. Asian Soc. Sci., 6: 188-192.

Judge, T.A. and J.E. Bono, 2001. Relationship of core self-evaluations traits-self-esteem, generalized self- efficacy, locus of control and emotional stability-with job satisfaction and job performance: A meta-analysis. J. Applied Psychol., 86: 80-92.

Kim, S., 2002. Participative management and job satisfaction: Lessons for management leadership. Public Admin. Rev., 62: 231-241.
Koh, H.C. and E.H.Y. Boo, 2001. The link between organizational ethics and job satisfaction: A study of managers in Singapore. J. Bus. Ethics, 29: 309-324.

Kotter, J., 2012. Corporate Culture and Performance. Free Press, New York.

Lai, H.H., 2011. The influence of compensation system design on employee satisfaction. Afr. J. Bus. Manage., 5: 10718-10723.

Lambert, E. and N. Hogan, 2009. The importance of job satisfaction and organizational commitment in shaping turnover intent a test of a causal model. Criminal Justice Rev., 34: 96-118.

Lawler III, E.E. and L.W. Porter, 1967. The effect of performance on job satisfaction. Ind. Relation: J. Econ. Soc., 7: 20-28.

Locke, E.A., 1970. Job satisfaction and job performance: A theoretical analysis. Organiz. Behav. Hum. Performance, 5: 484-500.

Lund, D.B., 2003. Organizational culture and job satisfaction. J. Bus. Ind. Marketing, 18: 219-236.

Mathis, R.L. and J.H. Jackson, 2002. Human Resource Management: Essential Perspectives. 2nd Edn., Western College Publishing, USA.

McGivern, M.H. and S.J. Tvorik, 1997. Determinants of organizational performance. Manage. Dec., 35: 417-435.

Mondy, W.R., 2008. Human Resource Management. Pearson Education, New Jersey, USA., ISBN: 978- 81-317-2568-9, Pages: 385.

Mulyono, S. and J.A. Nasir, 2012. Mapping the organizational culture on basic leadership style and influence on performance lecturer. Manage. Bus., 11: 194-212.

Na, J., I.H. Amzat and J.H. Abolhaija, 2011. A study of lecturers'job satisfaction in selected Harbin city Universities, China. Interdiscip. J. Contemp. Res. Bus., 3: 17-39.

Nawab, S. and K.K. Bhatti, 2011. Influence of employee compensation on organizational commitment and job satisfaction: A case study of educational sector of Pakistan. Int. J. Bus. Soc. Sci., 2: 25-32.

Noe, R.A., 2008. Employee Training and Development. 4th Edn., McGraw-Hill, USA., ISBN-13: 9780071259347, pp: 110.

Ostroff, C., 1992. The relationship between satisfaction, attitudes and performance: An organizational level analysis. J. Applied Psychol., 77: 963-974.

Paik, Y., K.P. Parboteeah and W. Shim, 2007. The relationship between perceived compensation, organizational commitment and job satisfaction: The case of Mexican workers in the Korean Maquiladoras. Int. J. Hum. Res. Manage., 18: 1768-1781. 
Petty, M.M., G.W. McGee and J.W. Cavender, 1984. A meta-analysis of the relationships between individual job satisfaction and individual performance. Acad. Manag. Rev., 9: 712-721.

Raharjo, M.D., 2001. Islam and Socio-Economic Transformation. Lesfi Publication, Jakarta, Indonesia,

Reyes, P. and H.S. Shin, 1998. Work redesign and teacher outcomes in American public school. Korean J. Comp. Educ., 8: 335-358.

Ridwan, 2013. The role of Islamic work ethics against locus of control relationship with employee performance. Trikonomik, 12: 72-84.

Robbins, S., 1996. Organizational Behavior. Interpreting Hadyana Pudjaatmaka, Jakarta, Indonesia,

Robbins, S.P., 1989. Organizational Behavior: Concepts, Controversies and Applications. Prentice Hall, New Jersey.

Rogga, K.L., 2001. Human resources practices, organizational climate and employee satisfaction. Acad. Manage. Rev., 36: 619-644.

Sangadji, E.M., 2009. Influence of organizational culture and organizational leadership commitment on job satisfaction and impact on performance PAEDAGOGIA. Educ. Res. J., 12: 52-65.

Sangadji, E.M., 2013. The effect of organizational culture on lecturers job satisfaction and performance (A research in Muhammadiyah University throughout East Java). Int. J. Learn. Dev., 3: 1-18.
Sheridan, J.E., 1992. Organizational culture and employee retention. Acad. Manage. J., 35: 1036-1056.

Sopiah, 2013. The effect of compensation toward job satisfaction and job performance of outsourcing employees of islamic banks in Malang, Indonesia. Int. J. Learn. Dev., 3: 77-91.

Syed, A.A.S.G., N. Bhatti, S. Michael, F.M. Shaikh and H. Shah, 2012. Job satisfaction of faculty members of universities in Pakistan: A case study of university of Sindh-Jamshoro. Mod. Appl. Sci., 6: 89-95.

Tampubolon, B.D., 2007. Factor analysis of leadership style and work ethic factor against employee performance on organization that has applying. BSN. Res. Dev. J., 9: 106-115.

Tett, R.P. and J.P. Meyer, 1993. Job satisfaction, organizational commitment, turnover intention and turnover: Path analyses based on meta-analytic findings. Personnel Psychol., 46: 259-293.

Wiyono, M.P., 2009. Lecturer in quality assurance program. J. Sci. Educ., 16: 57-69.

Yousef, D.A., 2000. Organizational commitment: A mediator of the relationships of leadership behavior with job satisfaction and performance in a nonwestern country. J. Manage. Psychol., 15: 6-24.

Yousef, D.A., 2001. Islamic work ethic-a moderator between organizational commitment and job satisfaction in a cross-cultural context. Personnel Rev., 30: 152-169. 